Nat'l Bank in Albuquerque v. Robinson ${ }^{5 x}$ may be criticized. The circuit court of appeals held that the state statute providing for the liquidation or reorganization of insolvent corporations was suspended because the federal government had occupied the field under section $77 \mathrm{~B}$. If, despite the reasons advanced in this note in support of state jurisdiction in the reorganization field, state receivership statutes are held suspended under the reasoning of the Robinson case, states may nevertheless continue to exercise jurisdiction over reorganizations through the equity receivership. That this may be true is indicated by the attempt of counsel in the Robinson case to have the receivership treated as an equity proceeding, and by the reply of the court that the receiver was appointed under the state statute. This distinction, between an equity receivership and a state statutory receivership, receives further support from the statement in In re Sterba ${ }^{52}$ that the remedy of an equity receivership is not the equivalent of a proceeding under the reorganization acts. Hence it may be contended that federal legislation which suspends similar state statutes has no effect on the equity receivership, apart from the power of a federal court to supersede an equity proceeding. ${ }^{33} \mathrm{An}$ analogy in support of this result is found in the previous discussion of the assignment for the benefit of creditors: the assignment has been sustained, even though statutory assignments have been suspended, because it is a remedy which existed at common law. ${ }^{4}$ This approach, however, results in a return to the equity receivership, the evils of which reorganization legislation was intended to obviate. Nevertheless, the states should have the power to regulate the equity receivership for the purpose of eliminating its evils, as they have been held to have the power to provide legislative safeguards for the administration of assignments for the benefit of creditors. 55

\title{
NEGRO RESTRICTIONS AND THE "CHANGED CONDITIONS" DOCTRINE
}

During the last two decades many property owners in our larger cities have entered into covenants prohibiting the sale or rental of real estate to Negroes. Subdividers have included the restrictive covenant in deeds of conveyance, and "improvement associations" in already established residential neighborhoods have encouraged property owners in a given area to sign and record group agreements limiting the use or sale of their respective parcels to members of the

${ }^{5 x}$ ro7 F. (2d) 50 (C.C.A. roth 1939); see Effect of National Bankruptcy Act on State Insolvency Statutes, 49 Yale L. J. Iogo (r940). Contra: Gallagher v. Keystone Realty Holding Co., 333 Pa. 9, 3 A. (2d) 426 (I939) (upholding the appointment of a receiver for a corporation under a state statute whose discharge feature had been suspended (see note ig supra). The court followed the intention of Congress argument (see notes $43-4,47^{-9}$ supra, and related text)).

${ }^{52} 74$ F. (2d) 4 r3 (C.C.A. $7_{\text {th }}$ 9935). But cf. Finletter, Bankruptcy Reorganization 3 (r939). 53 See note 39 supra.

${ }^{54}$ See note 24 supra. 55 See note 20 supra. 
Caucasian race. ${ }^{x}$ Since the adoption of these covenants, the "Negro situation" in many instances has so materially changed that some of the covenantors, or their successors, ${ }^{2}$ have become handicapped by the restriction. When the threat of a Negro invasion becomes imminent, property owners in the center or at the far edge of the restricted tract enjoy the first concrete evidence of the restriction's utility, but possibly at the expense of the near-edge owners. If the latter find themselves unable to rent or sell to white prospects because Negroes have settled across the street, they may feel morally justified in refusing to remain a "front line defense."

Damage actions for violation of Negro restrictions are rare, probably both because of the difficulty in measuring damages for many and variously-situated plaintiffs, and because such actions do not effect the desired result: keeping the area restricted. Forfeitures under a right of re-entry for condition broken

× The constitutionality of this private means of racial segregation is firmly established, Corrigan v. Buckley, 27 I U.S. 323 (I926); Queensboro Land Co. v. Cazeaux, I36 La. 724, 67 So. 64I (I9I5); Koehler v. Rowland, 275 Mo. 573, 205 S.W. 217 (I9I8); Los Angeles Investment Co. v. Gary, x8I Cal. 680, I86 Pac. 596 (I9I9); Parmelee v. Morris, 2I8 Mich. 625, r88 N.W. 330 (r922); Ridgway v. Cockburn, r63 Misc. 5 II, 296 N.Y. Supp. 936 (S. Ct. r937). Illinois, Colorado, Maryland, Kansas, Virginia, West Virginia, and Alabama take the same view, and no state has yet held to the contrary, Bruce, Racial Zoning by Private Contract, 2 IIl. L. Rev. 707 (1927).

Municipal residence ordinances, intended to segregate Negroes, were declared violative of the due process clause of the Fourteenth Amendment in Buchanan v. Warley, 245 U.S. 60 (rgr7). See also Harmon v. Tyler, 273 U.S. 668 (I927), reversing Tyler v. Harmon, 160 La. 943, 107 So. 704 (r926); Liberty Annex Co. v. Dallas, 289 S.W. 1067 (Tex. Civ. App. r927).

Covenants prohibiting the sale of the premises to Negroes have been declared void by some states as contrary to public policy, or, in the case of a conveyance, as repugnant to the fee simple estate granted; but the same courts have upheld restrictions upon the use or occupancy of the premises by Negroes, thus effecting the desired result, Los Angeles Investment Co. v. Gary, I8I Cal. 680, I86 Pac. 59 (Igrg); Porter v. Barrett, 233 Mich. 373, 206 N.W. 532 (1925); White v. White, 108 W.Va. I28, I50 S.E. 531 (r929). Other states have enforced sale restrictions at least where there is a reasonable time limitation on the covenant, Queensboro Land Co. v. Cazeaux, 136 La. 724, 67 So. 64I (1915) (twenty-five years); Koehler v. Rowland, 275 Mo. 573, 205 S.W. 217 (I9I8) (twenty-five years); Russell v. Wallace, 30 F. (2d) 98I (App. D.C. I929) (no time limit); Chandler v. Ziegler, 88 Colo. I, 29I Pac. 822 (I930); Lee v. Hansberry, 372 IIl. 369, 24 N.E. (2d) 37 (I939), noted in 7 Univ. Chi. L. Rev. 563 (I940) (no final time limit, but a provision that after twenty years the contract could be abrogated by written agreement of the owners of 75 per cent of the frontage); see Clark v. Vaughan, r3 I Kan. 438, 292 Pac. 783 (I930); Eason v. Buffaloe, I98 N.C. 520, I52 S.E. 496 (I930); Ridgway v. Cockburn, I63 Misc. 5 II, 296 N.Y. Supp. 936 (S. Ct. 1937).

2 Courts of equity uniformly hold that subsequent grantees must comply with the terms of the covenant, whether it was created in a deed of conveyance or by a recorded neighborhood agreement. "The question is not whether the covenant runs with the land, but whether a party shall be permitted to use the land in a manner inconsistent with the contract entered into by his vendor, and with notice of which he purchased," 3 Tiffany, Real Property, 472 (3d ed. r940). 
have been more frequently declared, ${ }^{3}$ but the vast majority of actions to enforce these restrictions involve injunction proceedings. ${ }^{4} \mathrm{~A}$ defense frequently invoked in such a suit is that of "changed conditions." It is a well-established principle that where conditions have so materially changed since the inauguration of a restrictive covenant that its purpose has failed and its enforcement would work undue hardship upon the defendant with no substantial benefit to the plaintiffs, equity will refuse to issue an injunction. ${ }^{5}$

The Kansas Supreme Court in Clark v. Vaughan, ${ }^{6}$ recognizing the hardship imposed upon "front line" property owners where a Negro district had expanded to their street, denied an injunction on the ground that it would be inequitable to force the defendants to suffer virtual confiscation of their property to protect inner property, which was not in turn protecting them. But the dissent in the Clark case, voicing the attitude of most courts, ${ }^{7}$ pointed out that this is the exact situation the parties must have contemplated when they entered into the agreement. They contracted to keep Negroes out of the area, obviously knowing that they were powerless to prevent them from occupying adjacent territory. In other words, there had been no unforeseen change which had defeated the purpose of the restriction. In Porter v. Johnson, ${ }^{8}$ the Missouri Appellate Court, in denying the applicability of the changed conditions doctrine in similar circumstances, unnecessarily added the questionable argument that the restriction created an easement in favor of the owners of the other parcels, and that this easement was a property right which could not be taken away without eminent domain proceedings.

How much weight should a court of equity give the changed conditions defense in Negro restriction cases?

3 Koehler v. Rowland, 275 Mo. 573, 205 S.W. 217 (I9r8); Los Angeles Investment Co. v. Gary, I8I Cal. 680, I86 Pac. 596 (rgrg). Probably a court will be more hesitant about enforcing a forfeiture provision if the right of entry is vested in a remote grantor or his heirs, and the district is definitely "going colored." See Letteau v. Ellis, I22 Cal. App. 584 , ro P. (2d) $49^{6}$ (I932).

4 The mere fact that the covenant contains a penalty provision does not preclude enforcement in equity, Torrey v. Wolfes, 6 F. (2d) 702 (App. D.C. I925) (\$2000 penalty provision).

In Queensboro Land Co. v. Cazeaux, I36 La. 724, 67 So. 64 I (I9r5), the covenant provided for injunction and damages as the remedies, but the grantor asked for rescission from his grantee who had reconveyed to a Negro. It was held that rescission would be a proper remedy, but that the defendant would first be given an opportunity to get a reconveyance from the Negro in order to preserve his original bargain purchase from the plaintiff.

5 Trustees of Columbia College v. Thacher, 87 N.Y. 3II (1882) (building restriction); Ewertson v. Gerstenberg, I86 Ill. 344, 57 N.E. I05I ( $\mathrm{g} 900$ ) (building line); Windemere-Grand Improvement and Protective Ass'n v. American State Bank of Highland Park, 205 Mich. 539, $x_{72}$ N.W. 29 ( $x_{9} x_{9}$ ) (building restriction); see Rombauer v. Christian Church, 328 Mo. I, 2x, 40 S.W. (2d) 545,554 ( $193 \mathrm{I}$ ).

${ }^{6} 3 x$ Kan. 438 , 292 Pac. 783 (1930).

7 Grady v. Garland, 89 F. (2d) 8I7 (App. D.C. I937); Mead v. Dennistone, I73 Md. 295, I96 Atl. 330 (I937); Porter v. Johnson, 232 Mo. App. Ir5o, II 5 S.W. (2d) 529 (I938).

${ }_{232}$ Mo. App. II5O, II5 S.W. (2d) 529 (I938). 
The changed conditions doctrine originated in cases involving restrictions upon the type, quality, position, and use of buildings. It has often been obscured by the additional defenses of waiver and acquiescence where the plaintiffs have failed to protest other violations, and by that of abandonment where numerous surrounding owners have violated the restriction.9 Furthermore, in the building cases the fact situations have been so varied, and have so often given rise to special equities, that it is extremely difficult to determine what types of changes will, in themselves, constitute a successful defense.

In discussing the advisability of applying the defense of change in circumstances to the Negro restriction cases it will be helpful to distinguish the following three situations: (I) where the change has occurred outside the restricted area, but not within; (2) where the change has occurred within the restricted area, but only in a well-defined part of it; and (3) where a general change has occurred within the restricted area.

Although some courts in building cases have held that changes outside of the restricted tract will not justify refusal of equitable enforcement, ${ }^{x 0}$ others adhere to the opposite view. ${ }^{1 x}$ Perhaps the latter are justified in allowing surrounding changes to defeat enforcement in certain building situations, but this "lenient" attitude should not prevail in Negro cases. In the first place, the difference in the size of the area affected may warrant different treatment. Inasmuch as building restrictions are often imposed upon only a small group of lots, a surrounding change which affects one lot will directly affect the other parcels and tend completely to defeat the purpose of the restriction. But where, as in the typical covenant against Negroes, a large area is involved, an outside change affects only that part of the area adjacent to the boundary. Secondly, in a building case, the change may be one entirely unforeseen. For example, if a large stockyard were unexpectedly built on the edge of a subdivision restricted to homes of expensive construction, the covenant certainly should be deemed unenforceable, for no one could be expected to build a costly residence "back of the yards." The possibility of an infiltration of Negroes into adjacent areas, on the other hand, is not only foreseen, but probably the moving cause of the contract. ${ }^{{ }^{2}}$ Finally, a property owner on the edge of a tract restricted to residences might forceably argue that surrounding changes have so altered the situation

9 See Ewertson v. Gerstenberg, I86 IIl. 344, 57 N.E. IO5I (I900); Starkey v. Gardner, I94 N.C. $74, I_{3} 8$ S.E. 408 (I927).

ro Pagenstecher v. Carlson, I46 App. Div. 738, I3I N.Y. Supp. 4r3 (rgrr); Bohm v. Silberstein, 220 Mich. 278, I89 N.W. 899 (1922); Rombauer v. Christian Church, 328 Mo. I, 40 S.W. (2d) 545 (I93I).

II Trustees of Columbia College v. Thacher, 87 N.Y. 3 II (I882); Jackson v. Stevenson, 156 Mass. 496, 3I N.E. 69I (1892); Windemere-Grand Improvement and Protective Ass'n v. American State Bank of Highland Park, 205 Mich. 539, I72 N.W. 29 (I9r9); Downs v. Kroeger, 200 Cal. 743, 254 Pac. Iror (1927).

I2 See dissenting opinion of Jochems, J. in Clark v. Vaughan, I3I Kan. 438, 445, 292 Pac. 783,787 (r93o). 
that a store upon his property would benefit not only him, but also the owners throughout the tract. It may be more convenient for the residents in the protected tract if a shopping district, just outside the area, were allowed to expand across the street instead of being forced to spread out on only one side. A similar argument in a Negro case certainly could not be advanced.

If, however, outside changes cause the court to make an exception of borderline property, the result might be to create a boundary which, by successive exceptions, would recede until the entire restriction had been destroyed. ${ }^{13}$ Permitting boundary exceptions results in the second situation, a change within a well-defined part of the restricted area. In building cases it has been held that such a change will not, in itself, justify a violation of the covenant in a distinctly separate part of the tract; ${ }^{14}$ application of this rule usually enables the courts to prevent total destruction of the restriction, but only if there is no danger of a constantly receding border. Where a streetcar line, for example, is held to justify the building of business property on one street there is little possibility that owners on the next street back will construct more stores. And even if business demands did warrant their construction, the justification of a streetcar line would be absent. On the other hand, in the Negro cases, since the owners in each new "front line" would have the same justification their predecessors had, a constantly receding border is the almost inevitable result of making boundary exceptions.

Thus the changed conditions doctrine should be applied to Negro covenants, if at all, only in the third situation-where there has been a general change within the restricted area. Such a change, being in most instances unforeseen, justifies a court of equity in refusing enforcement. But even here, the hardships imposed by the restriction in a district which has become dotted with Negro residents, could be alleviated without the changed conditions doctrine. If numerous uncontested violations constituted the change, the defenses of waiver and abandonment should suffice. If there had been no violations, but Negroes had legally been able to occupy many homes because a sizable minority of the owners had refused to enter into the agreement, enforcement could be denied by holding that the parties intended the covenant to become effective only if signed by substantially all the owners within the designated territory. ${ }^{\mathrm{IS}}$ In Foster v. Stewart ${ }^{16}$ the California Appellate Court adopted this attitude, point-

${ }^{13} 44$ Harv. L. Rev. 989 (r93 I).

${ }_{14}$ Cassidy v. Kruvant, 97 N.J. Eq. 372, x27 Atl. 339 (1925); Vorenberg v. Bunnell, 257 Mass. 399 , I 53 N.E. 884 (I926).

${ }_{15}$ The doubt as to exactly how much of the tract must be included to render the covenant effective is eliminated if the instrument itself provides that it must contain a given number of valid signatures, Oberwise v. Paulos, ${ }_{24}$ Cal. App. 247 , I2 P. (2d) $1_{56}\left(\mathrm{Ig3}_{2}\right)$, or the signatures of the owners of a certain percentage of the frontage in the described area, Burke v. Kleiman, 277 IIl. App. 519 (r934) (95 per cent required).

${ }^{36}{ }_{34}$ Cal. App. 482, 25 P. (2d) 497 (I933); see Thornhill v. Herdt, r3o S.W. (2d) 775 (Mo. App. 1939). 
ing out that "no equitable principles exist upon which to base a decree prohibiting a lot owner from renting or conveying his lot to one other than of the Caucasian race while the owners of lots on both sides are left free to lease, rent, or to convey to whomsoever they please." Since enforcement should certainly be denied in these cases of general change within the district, the practicability of maintaining the tenuous distinction between changed conditions and other equitable defenses might be questioned. But if the distinction is preserved, and the courts were to realize that the changed conditions doctrine need not be invoked even in this group of cases, perhaps there would be less chance of their misapplying the doctrine to situations, like that in the Clark case, ${ }^{17}$ where the change is outside the restricted area and the other equitable defenses are unavailable. ${ }^{\mathrm{x}}$

Negro restrictive covenants may or may not be socially desirable; the foregoing considerations merely indicate that as long as society permits them, courts should strictly enforce them. Courts should be reluctant to refuse enforcement of an agreement upon which the plaintiffs have relied, merely because it has proved disadvantageous to the defendants. Furthermore, covenantors should not be encouraged to rely upon the "leniency" of courts of equity to protect them in the event of extreme changes, for this protection is partly illusory. Even where there is such a complete change of conditions that an injunction is unquestionably denied, most courts have refused to declare the right to other remedies extinguished. ${ }^{\mathrm{x}}$ As a result, after the restriction has become ineffectual, the property owner may find that the remote possibility of an action for damages affects the marketability of his title. ${ }^{20}$ The Supreme Court of Missouri, in Pickel v. McCawley, ${ }^{2 \mathrm{x}}$ an action to quiet title, decreed that since the settling of Negroes throughout the district had rendered the covenant void, the title was clear of the restriction. But until other states follow the lead of Missouri, ${ }^{22}$ the breaking down of a restrictive covenant by application of the changed condi-

${ }^{27}$ Note 6 supra.

${ }^{8}$ It would possibly be desirable to utilize the changed conditions doctrine in the almost inconceivable situation where the parties have expressly stipulated that the agreement is to become effective even though not signed by a sizable majority.

29 Grady v. Garland, 89 F. (2d) 8I 7 (App. D.C. I937); Clark, Covenants and Interests Running with the Land I64 (r929); 44 Harv. L. Rev. 989 (I93I).

${ }^{20}$ See United Co-op Realty Co. v. Hawkins, 269 Ky. 563, 108 S.W. (2d) 507 (I937).

${ }^{2 x} 329$ Mo. I66, 44 S.W. (2d) 857 (r93I).

32 The Supreme Court of Florida recently decreed a title clear of a building restriction because changed conditions had defeated its purpose, Barton v. Moline Properties, I2r Fla. 683, 164 So. 55 I (I935). Since building restrictions, unlike Negro covenants, are generally of indefinite duration, there is even greater necessity for their being completely extinguished by equitable decree. 
tions doctrine will leave a useless restriction, clouding titles and impairing sales and mortgage transactions. ${ }^{23}$

It is suggested that property owners enter into a Negro covenant in the future only after a careful analysis of its possible effects in the light of their individual circumstances. Then, if they decide that the restriction is desirable, they should expect strict enforcement from the courts, and protect themselves against extreme changes by drafting a covenant which includes a workable plan of voluntary abrogation, ${ }^{24}$ and, possibly, a scheme for contribution by all of the parties toward mitigating the special losses falling upon owners of boundary property.

${ }^{23}$ See Edwards v. West Woodridge Theatre Co., 55 F. (2d) 524 (App. D.C. I93I). See also Administrative Rules of the Federal Housing Administrator for Mutual Mortgage Insurance under section 203 of the National Housing Act, \& 5 (I) (July I, I939).

${ }_{24}$ If too large a majority is necessary for abrogation, the practical difficulty of securing numerous signatures may defeat the utility of the provision. See instrument set out in Burke v. Kleiman, 277 III. App. 5I9, providing that the agreement is to terminate on or after a set date if the owners of 75 per cent of the restricted frontage sign an agreement to abrogate; otherwise an automatic renewal is to occur. 